\title{
Evaluasi Program Regrouping Sekolah Dasar Negeri
}

\author{
Maria Tri Erowati \\ Magister Manajemen Pendidikan Universitas Kristen Satya Wacana \\ dirgantaranovan@gmail.com \\ Slameto \\ Magister Manajemen Pendidikan Universitas Kristen Satya Wacana \\ slameto_uksw@yahoo.com \\ Wasitohadi \\ Magister Manajemen Pendidikan Universitas Kristen Satya Wacana \\ wasitohadiuksw@gmail.com
}

\begin{abstract}
This research is an evaluation that aimed to know the process of implementation policy, factors that effected regrouping school program, the effects of regrouping, and how the effectiveness and efficiency of the regrouping program in SD Negeri Tukang 01 and 02, Pabelan, Semarang. This evaluation research used goal-free evaluation with the subject is SD Negeri Tukang 01 and 02 Pabelan. The collecting data used interview, observation, and documentation, then the data analysis was data reduction, data presentation, and drawing the conclusion. The result of this research showed that SD Negeri Tukang 01 and 02 already grouped for 4 years before the Regent\&\#39; letter published. Then, the students, teachers, government's rule, and school condition be the factors affected the regrouping program. This regrouping program has several impacts, they answered the teacher need and/or there was a teacher mutation. Then for students, there weren't much effect because the students already friends, and then increasing the school's facility. Besides that, regrouping program might increase school quality and the society would not be confused to choose the school for their child. But then, the alumni of these school can be difficult to get legalize for their certificate. This regrouping program is effective and efficient enough to do because the teacher problem can be solved, then the school facility can be maximized and about the budgeting organize by the main school.
\end{abstract}

Keywords: Goalfree Evaluation Model, Primary School Regrouping Program, Program Evaluation

\section{Article Info}

Received date: 30 Mei $2017 \quad$ Revised date: 9 Desember 2018 Accepted date: 9 Desember 2018

\section{PENDAHULUAN}

Proses regrouping sekolah di Indonesia sudah dimulai sejak terbitnya Peraturan Menteri Dalam Negeri Nomor 421.2/2501/ Bangda/1998 tentang Pedoman Pelaksanaan Penggabungan (Regrouping) Sekolah Dasar (Kemendagri, 1998). Tujuan regrouping 152 tersebut adalah untuk mengatasi masalah kekurangan tenaga guru, peningkatan mutu, efisiensi biaya bagi perawatan gedung sekolah dan sekolah yang ditinggalkan dimungkinkan penggunaannya untuk rencana pembukaan SMP kecil/SMP kelas jauh atau setara sekolah lanjutan sesuai ketentuan setempat untuk 
Evaluasi Program Regrouping Sekolah Dasar Negeri | Maria T. Erowati, dkk.

menampung lulusan sekolah dasar. Dalam perkembangannnya telah lahir berbagai kebijakan yang mengatur regrouping sekolah di negeri ini. Undang-undang Nomor 25 Tahun 2000 tentang Program Pembangunan Nasional (Propenas) Tahun 2000-2004 misalnya, antara lain menentukan bahwa salah satu kegiatan pokok dalam mengupayakan pemerataan pendidikan dasar adalah melaksanakan revitalisasi serta penggabungan (regrouping) sekolah-sekolah terutama SD, agar tercapai efisiensi dan efektivitas sekolah yang didukung dengan fasilitas yang memadai. Pada tahun 2002 terbit Keputusan Menteri Pendidikan Nasional Nomor 060/U/2002 tentang Pedoman Pendirian Sekolah yang antara lain menentukan bahwa 1) pengintegrasian sekolah merupakan peleburan atau penggabungan dua atau lebih sekolah yang sejenis menjadi satu sekolah, dan 2) sekolah hasil integrasi merupakan bentuk sekolah baru (pasal 23). Sekolah yang diintegrasikan mengalihkan tanggung jawab edukatif dan administratif peserta didik dan tenaga kependidikan kepada sekolah hasil integrasi.

Sejalan dengan berlakunya kebijakan desentralisasi bidang pendidikan di tingkat Propinsi dan Kabupaten/ Kota - sebagaimana terakhir diatur melalui Undang Undang Nomor 23 tahun 2014 tentang Pemerintahan Daerahmaka setiap propinsi lazimnya menetapkan Peraturan Daerah yang antara lain mengatur soal regrouping sekolah. Di propinsi Jawa Tengah hal itu diatur dalam Peraturan Daerah Provinsi Jawa Tengah Nomor 4 Tahun 2012 tentang Penyelengagaraan Pendidikan, yang antara lain juga mengatur kewenangan para pihak dalam melakukan penggabungan sekolah. Kewenangan itu selanjutnya diatur lebih rinci melalui Peraturan Gubernur Nomor 56 tahun 2013 tentang Petunjuk Pelaksanaan Peraturan Daerah Provinsi Jawa Tengah Nomor 4 Tahun 2012 tentang Penyelenggaraan Pendidikan, yang antara lain menentukan bahwa "Bupati/Walikota sesuai dengan kewenangannya dapat melakukan penambahan, perubahan, penggabungan dan penutupan satuan pendidikan formal pada jenjang Pendidikan Anak Usia Dini (PAUD), Pendidikan Dasar (DIKDAS), Pendidikan Pendidikan Menengah (DIKMEN) dan satuan pendidikan nonformal sesuai ketentuan peraturan perundang- undangan" (pasal 6 ayat1).

Berdasarkan kewenangan di atas maka itu setiap Kabupaten /Kota lazimnya kemudian menetapkan Peraturan Bupati atau Peraturan Walikota tentang regrouping/penggabungan sekolah. Di Kabupaten Semarang telah terbit Peraturan Bupati Nomor 28 Tahun 2014 tentang Pedoman Teknis Penggabungan Sekolah Dasar Negeri dan ditandaklanjuti dengan Keputusan Bupati Nomor 900/0413/2014 tentang Penetapan Penggabungan Sekolah Dasar Negeri di Kabupaten Semarang. Istilah regrouping merupakan kata lain dari merger/penggabungan. Merger pada awalnya merupakan salah satu usaha pengembangan dan pertumbuhan perusahaan. Merger dilakukan dengan menggabungkan dan membagi sumber daya yang dimiliki perusahaan untuk mencapai tujuan bersama. Adrian Sutedi (2007: 85) mengemukakan, "merger sebagai suatu bentuk penggabungan dua badan usaha, badan usaha yang satu tetap ada, dan yang satunya lagi bubar secara hukum, dan nama perusahaan digunakan adalah perusahaan yang eksis/ada." Jadi merger merupakan penggabungan dua badan usaha atau lebih menjadi satu badan usaha ke dalam badan usaha yang eksis dengan nama badan usaha yang tetap eksis. Penggabungan badan usaha ini mengharuskan adanya peleburan aset secara menyeluruh ke dalam badan usaha yang tetap eksis. Hal ini secara kuantitas akan memberikan tambahan modal bagi badan usaha yang eksis tersebut.

Merger/penggabungan dapat juga diterapkan di dalam dunia pendidikan. Mergerl penggabungan dalam dunia pendidikan lebih 
berkaitan dengan perampingan jumlah sekolah. Jumlah sekolah yang cukup banyak dengan jumlah siswa yang kurang memadai berdasarkan standar nasional mengakibatkan pemborosan pembiayaan pendidikan. Untuk itu, pemerintah mengupayakan alternatif perampingan sekolah dengan nama regrouping. Menurut Wibawa (2009: 47), "penggabungan sekolah dasar merupakan satu cara pengembangan sekolah dengan memberdayakan dan mengembangkan berbagai sumber daya pendidikan untuk mencapai peningkatan mutu pendidikan dan efektifitas sekolah."

Adapun tujuan regrouping sekolah menurut Suparlan (2006) meliputi (1) meningkatkan mutu layanan pendidikan untuk masyarakat. Dalam arti layanan pendidikan harus bermutu, bukan hanya layanan pendidikan dengan gedung sekolah yang seadanya; (2) meningkatkan efisiensi penyelenggaraan pendidikan, karena keberadaan beberapa sekolah dalam satu kompleks gedung sekolah yang sempit menimbulkan indikasi terjadinya proses persaingan yang tidak sehat antara sekolah yang satu dengan yang lain, sehingga perlu dilakukan regrouping sekolah.

Sedangkan langkah-langkah regrouping sekolah yang ideal menurut Suparlan (2006) antara lain mencakup: a) Mengadakan sosialisasi kebijakan merger sekolah kepada semua pemangku kepentingan (stakeholders). Langkah pertama ini dilakukan agar para pemangku kepentingan memiliki pemahaman mendalam tentang manfaat merger bagi semua pihak, terutama bagi peserta didik. Sosialisasi bukanlah instruksi, bukan pula pemaksaan terselubung. Benar-benar untuk meningkatkan pemahaman secara kritis tentang manfaat kebijakan merger sekolah sebagai strategi untuk meningkatkan mutu pendidikan; b) Membentuk tim atau kepanitiaan, dengan melibatkan komponen yang terkait. Pembentukan tim atau kepanitiaan ini pun harus dilakukan secara demokratis agar semua stakeholders dapat terakomodasi aspirasinya, dan yang lebih penting adalah agar dapat memberikan peran sertanya secara maksimal dalam penyelenggaraan pendidikan; c) Mengajukan atau memasukkan program merger sekolah ke dalam program dan kegiatan dinas pendidikan, untuk disetujui oleh pemerintah dan legislatif. Langkah ini penting, karena program merger akan memerlukan konsekuensi anggaran yang mungkin tidak sedikit; d) Pelaksanaan program dan monitoring pelaksanaan program melibatkan semua stakeholder yang sejak awal dilibatkan dalam program ini. Program ini dilaksanakan menurut prinsip manajemen modern, yakni demokratis, transparan, dan akuntabel. Jika tidak, maka justru akan terjadi distrust dari masyarakat; e) Pelaporan dan pertanggungjawaban jika program itu telah dapat diselesaikan. Di samping itu, kegiatan pasca pelaksanaan program perlu dilakukan, misalnya monitoring dampak pelaksanaan program tersebut terhadap peningkatan mutu pendidikan, sebagaimana telah disebutkan dalam tulisan ini, yakni lima dimensi mutu pendidikan: yakni 'learners, environments, content, processes, dan outcomes' atau peserta didik, lingkungan, kurikulum atau bahan ajar, proses pendidikan atau proses pembelajaran, dan hasil pendidikan atau hasil belajar peserta didik

Implementasi kebijakan peningkatan mutu pendidikan melalui program regrouping sekolah dasar telah diteliti oleh beberapa peneliti. Syahidah (2013) misalnya, meneliti tentang evaluasi kebijakan penggabungan Sekolah Dasar Negeri Kota Pekalongan, dengan temuan bahwa kebijakan regrouping sekolah sekolah yang berada di satu kawasan sudah berhasil dalam pencapaian efektifitas dan efesiensi pendidikan karena baik input, aktor maupun faktor pendukung terpenuhi sehingga implementasi kebijakan tidak mengalami kesulitan yang berarti. Namun 
kebijakan penggabungan manajerial memiliki banyak kendala dalam menuju efektifitas dan efesiensinya, karena adanya beban ganda yang diberikan kepada kepala sekolah sehingga terkendala dalam membagi waktu untuk dua sekolah.

Penelitian Dwiningrum \& Widiowati (2014) tentang proses regrouping sekolah yang terdampak erupsi Gunung Merapi di Yogyakarta menunjukkan bahwa faktor-faktor pendukung regrouping sekolah meliputi:

a) kebijakan pemerintah daerah; b) sponsorsponsor penyandang dana dalam pembuatan gedung baru untuk SD Negeri Umbulharjo 2; c) kemauan dari guru masing-masing sekolah untuk mendukung kebijakan regrouping demi kelancaran proses kegiatan belajar mengajar pasca erupsi Merapi; d) kesediaan guru melakukan pendampingan terhadap siswa dan senantiasa memberikan nasihat dan dukungan kepada siswa, dan e) siswa mau beradaptasi terhadap lingkungan sekolah yang baru. Sedang faktor penghambatnya adalah kurang luasnya pengetahuan guru dalam pemulihan psikologis anak paska erupsi Merapi, beban kerja guru sudah tinggi, problem internal dari guru itu sendiri, serta kurangnya kreatifitas dan inovasi guru mengajar paska erupsi Merapi.

Sementara itu penelitian Waluya (2014) tentang pelaksanaan program regrouping Sekolah Dasar 1 Undaan Tengah, Kecamatan Undaan, Kudus, menunjukkan bahwa pelaksanaan program regrouping di SD 1 Undaan Tengah berjalan dengan sangat baik sesuai dengan yang diharapkan. Pengelolaan sekolah menjadi lebih efisien dan efektif serta pembelajaran mampu mencapai standar yang ditetapkan. Sarana dan prasarana mengalami peningkatan, meskipun masih perlu perbaikan dan pengadaan. Sedang penelitian evaluasi Purwaningsih (2014) terhadap implementasi program regrouping sekolah dasar di Kabupaten Purworejo, menunjukan bahwa:

a) implementasi kebijakan regrouping di sekolah dasar diawali dengan pendataan terhadap sekolah-sekolah dasar yang nantinya dipetakan berdasarkan skala prioritas oleh Tim Penghapusan dan Penggabungan Sekolah; b) monitoring dilaksanakan secara non formal insidental dalam upaya menjaga agar pelaksanaan regrouping sesuai dengan tujuan yang telah direncanakan, strategi yang digunakan dengan memberikan motivasi negatif bagi sekolah yang akan di regrouping; c) evaluasi program regrouping menujukkan ketercapaian tujuan, yaitu pemenuhan standar pelayanan minimal pendidikan, efisiensi anggaran, efektivitas penyelenggaraan pendidikan, dan adanya peningkatan mutu pendidikan bagi sekolah regrouping, baik dari segi akademis maupun non akademis.

Sementara itu, penelitian Hills (2013) dengan tentang regrouping sekolah di New Zealand, menunjukkan bahwa penutupan dan penggabungan sekolah dapat menyebabkan perbedaan budaya masyarakat yang signifikan.

Dari lima penelitian tentang regrouping diatas, hanya satu yang membahas tentang evaluasi kebijakan regrouping sekolah, yang memberikan suatu rekomendasi kepada pemangku kepentingan untuk mengkaji ulang tentang efektifitas program regrouping manajerial sekolah. Sementara tiga penelitian lain membahas implementasi program regrouping yang mengalami berbagai permasalahan, khususnya di lingkungan sekolah yang digabungkan. Satu penelitian membahas tentang dampak yang ditimbulkan oleh program regrouping bagi masyarakat sekitar sekolah. Kesamaan dari lima penelitian di atas sama-sama menggunakan pendekatan deskriptif, yang memberi gambaran yang jelas tentang program regrouping sekolah. Penelitian yang penulis lakukan saat ini, lebih menekankan pada evaluasi program regrouping sekolah, yang mencakup evaluasi terhadap proses pelaksanaan regrouping sekolah, faktorfaktor yang mempengaruhi, dampak yang timbul, serta efektifitas dan efisiensi dari program regrouping sekolah tersebut. 
Kelola: Jurnal Manajemen Pendidikan, Vol. 5, No. 2, Juli-Desember 2018

Evaluasi adalah suatu kegiatan mengumpulkan, menganalisis, dan menyajikan informasi dengan cara membandingkan antara kegiatan yang direncanakan terhadap kegiatan yang dilaksanakan dan membandingkan antara tujuan program terhadap hasil yang tercapai, yang selanjutnya informasi tersebut digunakan untuk mengetahui efektivitas dan efisiensi proyek, kebijakan dan program yang dipakai untuk menentukan alternatif yang tepat dalam mengambil suatu keputusan (Arikunto \& Cepi 2009: 2; Wirawan, 2011: 7). Sedangkan pengertian dari evaluasi program adalah metode sistematik untuk mengumpulkan, menganalisis, dan memakai informasi dengan tujuan untuk mengetahui efektivitas dan efisiensi proyek, kebijakan dan program (Wirawan, 2011: 17; Weiss dalam Sugiyono, 2010: 741; dan Sugiyono, 2010: 742). Sementara itu tujuan dari evaluasi program adalah untuk mengetahui apakah tujuan program telah tercapai dan serta mengetahui penyebab-penyebabnya yang selanjutnya hasil evaluasi dapat digunakan untuk mengambil keputusan tentang keberlanjutan sebuah program perlu diteruskan, diperbaiki atau dihentikan (Wirawan, 2011: 17; Arikunto \& Cepi, 2009: 18).

Pada tahun 2014 Kabupaten Semarang berhasil melakukan penggabungan $25 \mathrm{SD}$ negeri menjadi $12 \mathrm{SD}$, yang salah satunya adalah SD Negeri Tukang 01 dan 02 Kecamatan Pabelan, Kabupaten Semarang yang kemudian menjadi Sekolah Dasar Negeri Tukang. Dari penggabungan itu, diharapkan pemangku kepentingan, warga sekolah, dan masyarakat sepaham dan mendukung penggabungan tersebut (Ungaran, Kompas.com, 6/1/2014), karena tujuan utama regrouping sekolah adalah tercapainya efisiensi dan efektifitas pengelolaan pendidikan di sekolah yang bersangkutan. Permasalahannya adalah apakah dengan diimplementasikannya program regrouping ini akan mengubah kualitas pendidikan di SD Negeri Tukang. Oleh karena itu penulis merasa perlu melakukan evaluasi terhadap program regrouping di SD Negeri Tukang 01 dan 02, baik mengenai proses implementasi, faktor-faktor yang mempengaruhi, dampak serta peningkatan efektifitas \& efisiensi dari program regrouping sekolah.

\section{METODE PENELITIAN}

Penelitian ini merupakan penelitian evaluatif menggunakan pendekatan diskriptif kualitatif. Pendekatan deskriptif kualitatif berusaha menggambarkan dan menginterpretasi objek sesuai dengan apa adanya. Penelitian ini dimaksudkan untuk menggambarkan serta menguraikan secara evaluativ keadaan atau fenomena tentang pelaksanaan, faktor, dampak dan tujuan regrouping yaitu efektifitas dan efisiensi dari program regrouping sekolah. Model evaluasi yang digunakan adalah Goal Free Evaluation yaitu evaluasi bebas tujuan, dimana peneliti berupaya mengevaluasi secara obyektif program regrouping yang dihubungkan dengan faktor-faktor pendukung dan penghambat kebijakan yang dijalankan, melihat sejauhmana tujuan regrouping tersebut tercapai, dan memperhatikan dampak dari penyelenggaraan program regrouping dalam konteks secara umum tanpa harus dibatasi oleh tujuan khusus dari program kebijakan yang telah direncanakan.

Tempat penelitian adalah SD Negeri Tukang 01 dan SD Negeri Tukang 02 Kecamatan Pabelan, Kabupaten Semarang. Sedang subyek dalam penelitian ini adalah Kepala Sekolah, pendidik, Ka. UPTD dan stakeholder SD Negeri Tukang 01 dan 02 Kecamatan Pabelan Kabupaten Semarang. Teknik pengumpulan data meliputi wawancara, observasi dan studi dokumen. Instrumen pengumpulan data berupa lembar wawancara, lembar observasi dan panduan studi dokumen. Untuk menguji keabsahan data pada penelitian ini digunakan teknik triangulasi sumber dan tringulasi teknik. Sedang teknik analisis data 
yang digunakan adalah analisa data kualitatif yang meliputi penyajian data, reduksi data dan penarikan simpulan.

\section{HASIL PENELITIAN DAN \\ PEMBAHASAN}

\section{Hasil Penelitian}

\section{Implementasi Program Regrouping Sekolah}

Walaupun secara resmi Surat

Keputusan Bupati Semarang tentang regrouping SD Negeri Tukang $01 \& 02$ baru terbit pada tahun 2014, namun proses regrouping sekolah di sebenarnya sudah direncanakan oleh stekeholder dari kedua sekolah sejak tahun 2009. Pada saat itu terjadi kekosongan jabatan Kepala Sekolah SD Negeri Tukang 01 karena pebjabat lama purna tugas. Oleh karena itu terhitung sejak tanggal 1 September 2009 jabatan Kepala Sekolah SD Negeri Tukang 01 diampu oleh Kepala Sekolah SD Negeri Tukang 02. Selanjutnya melalui rapat terpadu tanggal 20 Mei 2010 yang dihadiri oleh Pengawas Sekolah TK-SD UPTD Pendidikan Kecamatan Pabelan, Komite Sekolah, dan Dewan Guru SD Negeri Tukang 01 dan 02 serta perangkat Desa setempat diputuskan bahwa mulai tahun ajaran 2010/2011 SD Negeri Tukang 01 tidak lagi menerima peserta didik baru dan hanya mengelola siswa kelas II sampai kelas VI. Sementara yang menerima peserta didik baru hanya SD Negeri Tukang 02.
Melalui proses regrouping sekolah jumlah tenaga pendidik yang semula belum memenuhi standar menjadi berlebih. Semula jumlah tenaga pendidik di SD Negeri Tukang 01 ada 7 orang, yang terdiri dari 6 guru kelas dan 1 guru Mapel Agama Islam. Sedang SD Negeri Tukang 02 memiliki 9 guru, terdiri dari 1 Kepala Aekolah, 6 guru kelas, 1 guru olah raga dan 1 guru mulok Bahasa Inggris. Jadi total jumlah tenaga pendidik setelah diregrouping ada 16 guru, yang terdiri dari 12 guru kelas, 1 guru mapel Agama Islam, 1 guru mapel Olah Raga dan 1 guru Mulok Bahasa Inggris. Sedangkan tenaga kependidikan yang dimiliki ada 2 orang yaitu 1 pustakawan dan 1 penjaga sekolah. Mengingat bahwa jumlah rombel yang ada di SD hasil regrouping (SD Tukang) hanya 6 (enam) maka terjadi kelebihan guru kelas. Oleh karena itu kemudian dilakukan mutasi sebagian guru ke SD lain di Kabupaten Semarang.

Hal yang sama juga terjadi dalan hal sarana prasarana pendidikan. Semua aset yang dimiliki oleh SD Negeri 01 diserahkan kepada SD Negeri Tukang 02. Aset yang berupa bangunan, mebeler, buku dan alat peraga dikelola oleh SD Negeri Tukang. Penggunaan sarana prasarana diatur sepenuhnya oleh SD Negeri Tukang sebagai sekolah induk yang menjadi naungan. Aset yang dimilik sebelum dan setelah regrouping dapat dilihat pada tabel 1 berikut ini.

Tabel 1. Data Sarana Prasarana Sekolah SD Negeri Tukang 02/SD Tukang

\begin{tabular}{|c|c|c|c|c|c|c|c|}
\hline \multirow{2}{*}{ NO } & \multirow{2}{*}{ Nama } & \multicolumn{3}{|c|}{ Sebelum Regrouping } & \multicolumn{3}{|c|}{ Setelah Regrouping } \\
\hline & & Jumlah & Ruang & Luas & Jumlah & Ruang & Luas \\
\hline 1 & Gedung Sekolah & 6 & 6 & 658 & 12 & 12 & 1488 \\
\hline 2 & Ruang Kepala Sekolah & 1 & 1 & 14 & 1 & 1 & 77 \\
\hline 3 & Ruang Guru & 1 & 1 & 35 & 1 & 1 & 35 \\
\hline 4 & Ruang Perpustakaan & 1 & 1 & 56 & 1 & 1 & 35 \\
\hline 5 & Ruang UKS & 1 & 1 & 35 & 1 & 1 & 35 \\
\hline 6 & Ruang Ibadah & 1 & 1 & & 1 & 1 & 54 \\
\hline 7 & Aula & 1 & 1 & 35 & 1 & 1 & 35 \\
\hline 8 & Gudang & 1 & 1 & & 1 & 1 & 22 \\
\hline 9 & Kamar Kecil & 3 & 3 & 18 & 7 & 1 & 34 \\
\hline 10 & Rumah Dinas Kepala Sekolah & 1 & 1 & 54 & 1 & 1 & 54 \\
\hline 11 & Rumah Dinas Guru & & & & 1 & 1 & 54 \\
\hline \multirow[t]{2}{*}{12} & Halaman & 1 & & 432 & 1 & & 682 \\
\hline & Total Area & & & 905 & & & 1487 \\
\hline
\end{tabular}

Sumber : Dokumen Data Absensi SD Negeri Tukang 02 Tahun 2010 dan 2017. 
Setelah selama 4 (empat) tahun SD Negeri 01 menjadi satu atap di SD Negeri 02, akhirnya pemerintah Kabupaten Semarang melalui Keputusan Bupati Semarang Nomor 900/0413/2014 tanggal 30 Mei 2014 menetapkan bahwa SD Negeri Tukang 01 dan SD Negeri Tukang 02 resmi diregrouping dengan nama baru SD Negeri Tukang. Dari tahun 2011 Panitia sudah mengajukan usul diregrouping, namun Bupati Kabupaten Semarang baru memberikan SK pada tahun 2014 dengan nama sekolah yang baru mengakibatkan permasalahan pada bidang administrasi sekolah. Semua administrasi sekolah yang lama tidak lagi dipergunakan, dan harus diarsipkan, dengan semua sejarah sekolah lama.

\section{Faktor-Faktor Yang Mempengaruhi Regrouping Sekolah}

Faktor-faktor yang mempengaruhi terjadinya regrouping dapat dilihat dari beberapa segi. Ada empat faktor yang memungkinkan terjadinya regrouping sekolah di SD Negeri Tukang $01 \&$ SD Negeri Tukang 02, antara lain (1) perundangundangan yang berlaku, (2) kondisi siswa, (3) kondisi tenaga pendidik, dan (4) kondisi lingkungan sekolah
Berbagai perundang-undangan baik di aras nasional maupun daerah (Provinsi dan Kabupaten) menjadi salah satu faktor yang memungkinkan terjadinya regrouping di SD Negeri Tukang 01 dan SD Negeri Tukang 02. Dalam perundang-undangan itu terdapat kriteria bahwa salah satu syarat sekolah yang diregrouping adalah sekolah berada dalam satu lokasi, sehingga SD Negeri Tukang 01 dan SD Negeri Tukang 02 masuk pada kategori sekolah yang dapat diregrouping, karena bukan hanya terletak di satu desa, tetapi kedua sekolah tersebut justru berada dalam satu lokasi yang menyebabkan persaingan tidak sehat antar warga sekolah.

Kondisi siswa juga menjadi faktor terjadinya regrouping. Jumlah siswa di SD Negeri Tukang 01 dan SD Negeri Tukang 02 dari tahun ke tahun tidak mengalami perkembangan. Rata-rata jumlah siswa setiap tahun hanya dikisaran angka 70 - 80 siswa. Setiap tahun jumlah siswa barupun hanya $10-$ 16 orang, sehingga dikatakan bahwa kedua sekolah tersebut adalah sekolah kurus sebagaimana tergambar pada tabel 2 berikut ini.

Tabel 2. Data PPDB SD Negeri Tukang 01 \& 02 Tahun 2007-2010

\begin{tabular}{cccc}
\hline No & Tahun & SDN 01 & SDN 02 \\
\hline 1 & 2006 & 7 & 13 \\
\hline 2 & 2007 & 11 & 12 \\
\hline 3 & 2008 & 12 & 12 \\
\hline 4 & 2009 & 12 & 10 \\
\hline 5 & 2010 & 15 & 16
\end{tabular}

Sumber : Data PSB SD N Tukang 01 \& SD Tukang 02 tahun 2007 - 2010.

Data di atas menunjukan bahwa jumlah siswa dari tahun ke tahun tidak memenuhi standar sekolah yang bermutu. Akan menjadi lebih baik jika kedua sekolah tersebut dilakukan regrouping sehingga dapat tercapai efektifitas dan efisiensi pengelolaan pendidikan.

Kondisi Guru adalah faktor ketiga bagi terjadinya regrouping SD N Tukang 01 dengan SD Tukang 02. SD Negeri Tukang 01 tidak memiliki guru Olahraga dan Kepala Sekolah. Setiap mata pelajaran olahraga, pelajaran itu langsung diampu oleh masing-masing guru kelas. Sementara tugas Kepala Sekolah dijalankan oleh salah satu guru senior, hingga pada akhirnya Ka.UPTD memberikan mandat kepada Kepala Sekolah SD Negeri Tukang 02 untuk mengampu jabatan sebagai Kepala Sekolah SD Tukang 01. Sementara SD Negeri 
Tukang 02 tidak memiliki masalah dalam hal tenaga pendidik. Semua sudah terpenuhi, baik itu guru kelas, olah raga maupun guru agama, dan seorang penjaga sekolah. Dengan demikian regrouping dipandang sebagai solusi atas masalah kekuarangan tenaga pendidik di SD Tukang 01.

Dari sisi lingkungan sekolah, di desa Tukang sebenarnya terdapat 3 (tiga) lembaga pedidikan dasar setingkat sekolah dasar, yaitu 1 (satu) Madrasah Ibtidaiyah (MI) dan 2 (dua) SD Negeri. Letak MI itu sendiri cukup jauh jaraknya dengan SD Negeri Tukang 01 dan SD Negeri Tukang 02. Tapi masih banyak masyarakat yang lebih berminat untuk menyekolahkan anak mereka di SD negeri. Masyarakat memberikan penilaian bahwa SD negeri lebih bermutu dibanding dengan MI yang ada di desa Tukang. Kondisi lingkungan kedua sekolah tersebut juga menjadi faktor penentu terjadinya regrouping. Terutama karena keberadaan sekolah yang satu kampus. Masyarakat secara umum lebih memilih sekolah di SD negeri menjadi keuntungan bagi sekolah. Namun masyarakat dibuat bingung dalam memilih satu diantara keduanya. Sehingga terbelah menjadi dua, sebagian mendukung SD Negeri Tukang 01 dan sebagian lagi di SD Negeri 02.

\section{Dampak Program Regrouping Sekolah}

Ada dua macamdampak regrouping bagi ketenagaan di sekolah yang bersangkutan yaitu dampak positif dan negatif. Dampak positif regrouping adalah terpenuhinya kebutuhan guru karena melalui regrouping itu semua kebutuhan guru kelas, guru mapel, dan guru mulok terpenuhi. Dampak negatifnya adalah munculnya kecemburuan para guru senior yang harus dimutasi ke sekolah yang lebih jauh. Sementara itu para guru honorer sekolah juga harus mencari sekolah lain yang lebih membutuhkan. Bagi guru honorer sekolah, walaupun masih dipertahankan di sekolah tersebut, namun mereka tidak mempunyai jam mengajar seperti waktu sebelum regrouping dilakukan. Peraturan baru pemerintah dalam peningkatan mutu pendidikan dan tuntutan sertifikasi guru, menyatakan bahwa sekolah parallel apabila jumlah siswa lebih dari 34 anak. Sementara guru yang mendapat tunjangan sertifikasi harus mengampu minimal 20 siswa dalam satu kelas. Apabila tidak memenuhi syarat tersebut maka data yang dientri lewat dapodik tidak valid. Oleh karena itu semua guru tetap cenderung mengajar penuh sehingga para guru honorer harus mencari sekolah lain yang bisa memenuhi jam mengajar mereka.

Regrouping sekolah bagi siswa tidaklah berdampak terlalu besar. Siswa yang sudah bergaul antara satu dengan yang lain, walaupun beda sekolah. Mereka tidak merasakan bahwa selama ini beda sekolah. Hal ini disebabkan karena mereka berada dalam satu kampus. Persaingan hanya mereka rasakan saat menghadapi lomba. Selebihnya dalam pergaulan sehari-hari, sebelum dan sesudah diregruping tidaklah berpengaruh. Dari segi jumlah, dua sekolah yang digabung menjadi satu berdampak pada peningkatan jumlah siswa dua kali lipat. Sebelum regrouping jumlah siswa dikisaran angka 70-80, setelah regrouping terjadi berada pada 140-155 siswa.

Regrouping sekolah di SD Negeri Tukang 01 dan SD Negeri Tukang 02 menghasilkan sekolah yang baru yaitu SD Negeri Tukang. Dengan regrouping, peningkatan mutu sekolah yang terlihat adalah: (1) Prestasi sekolah sejak dilakukan regrouping semakin meningkat. Hal ini terjadi karena sekolah memiliki banyak pilihan siswa yang berbakat. Sebelum diregrouping sekolah kesulitan memilih anak untuk mengikuti lomba karena keterbatan jumlah siswa. Namun setelah diadakan regrouping, bisa meraih banyak kejuaran yang baik tingkat kecamatan, kabupaten bahkan juga tingkat propinsi. (2) Tenaga pendidik. Mutu tenaga pendidik di SD Negeri Tukang juga mengalami peningkatan. Masing-masing kelas mendapatkan pola 
Kelola: Jurnal Manajemen Pendidikan, Vol. 5, No. 2, Juli-Desember 2018

pengajaran yang semakin berkualitas. Guru kelas yang masih muda dan berbakat memberikan metode pengajaran yang semakin kreatif. Terbukti anak-anak lulusan SD Negeri Tukang mendapatkan hasil ujian yang meningkat dari tahun ke tahun. Begitu juga ketika mengikuti berbagai macam lomba, guru memiliki dedikasi yang tinggi dalam melatih para siswa untuk mencapai kejuaraan. (3) Fasilitas/sarana prasarana sekolah. Hasil regrouping sekolah menjadikan sekolah baru memiliki fasilitas dan sarana prasarana yang semakin meningkat. Dengan memiliki banyak ruang kelas, sekolah dapat memanfaatkannya sebagai ruang pembelajaran yang baru, seperti ruang keterampilan, ruang olahraga, ruang kesenian, ruang pertemuan/aula dan gudang. Jadi pembelajaran tidak hanya dilakukan di dalam kelas masing-masing, tetapi dilakukan juga di ruang-ruang lain yang menunjang pelajaran mata pelajaran bidan umum maupun mata pelajaran muatan lokal.

\section{Dampak Terhadap Masyarakat}

Regrouping SD Negeri Tukang 01 dan SD Negeri Tukang 02 memiliki dampak positif dan negatif bagi masyarakat. Dampak positif yang dirasakan masyarakat adalah mereka tidak lagi merasa bingung harus menyekolah-kan anak mereka di SD Negeri Tukang 01 atau SD Negeri Tukang 02. Namun dampak negatifnya juga ada. Para alumni kedua sekolah tersebut kesulitan ketika meminta legalisir dari kedua sekolah tersebut. Karena hasil dari regrouping memunculkan nama sekolah baru, yang memiliki NPSN dan NSS yang berbeda. Para alumni merasa dirugikan karena sekolah yang mengeluarkan ijazah mereka sudah ditutup, walaupun sebenarnya data induk siswa masih ada di arsip sekolah baru. Sekolahpun tidak bisa memberikan surat keterangan untuk melegalisasi ijazah dari para alumni sekolah sebelum regrouping. Para alumni harus meluangkan waktu dan mengeluarkan dana yang lebih karena harus melegalisir ijazah mereka ke Dinas Kabupaten.

\section{Pencapaian Tujuan Regrouping Sekolah (Efektifitas Dan Efisensi dari Regrouping)}

Pencapaian tujuan awal program regrouping sekolah, yaitu pencapaian efisiensi dan efektifitas tenaga pendidik, keuangan dan sarana prasarana sekolah di SD Tukang adalah sebagai berikut. Efisiensi dan efektifitas pengelolaan tenaga pendidik telah tercapai karena melalui regrouping sekolah kebutuhan akan tenaga pendidik dengan sendirinya terpenuhi. Pemerintah tidak perlu lagi memboroskan uang untuk menggaji guru baru. Dari sisi keuangan, terjadi peningkatan jumlah penerimaan dana BOS. Sejak dilakukan regrouping, semua bentuk laporan keuangan menjadi tanggjawab sekolah hasil regrouping. Dana BOS dari pemerintah digabung menjadi satu atas nama SD Negeri Tukang 02, begitu pula dengan penggunaan dan laporan SPJ pengelolaan dana BOS. Sekolah lebih mampu menyelenggarakan proses pembelajaran yang lebih bermutu, melalui penambahan alat peraga pembelajaran dan sejenisnya.

Namun efektifitas dan efesiensi dalam pengelolaan sarana prasarana belum sesuai dengan yang diharapkan. Pengelolaan gedung sekolah, terutama kelebihan ruang kelas oleh sekolah hanya dijadikan ruang keseniaan, olah raga, keterampilan, dan gudang yang tidak setiap hari digunakan karena hanya dipakai pada saat-saat tertentu. Oleh karena itu bisa dikatakan ada pemborosan ruang gedung sekolah.

\section{Pembahasan Hasil Penelitian}

\section{Implementasi Program Regrouping Sekolah}

Hasil penelitian di atas menunjukkan bahwa proses implementasi program regrouping di SD Negeri Tukang 01 dan SD negeri Tukang 02 berjalan melalui proses persiapan yang cukup lama oleh stakeholder ke dua sekolah. Temuan ini sesuai dengan pendapat Suparlan (2006) bahwa proses regrouping memerlukan tahap di mana stakeholder sekolah memiliki pemahaman bersama tentang arti penting dan tujuan dari 
regrouping sekolah. Namun bentuk kegiatan yang terjadi dalam penelitian ini berbeda dengan pendapat Suparlan, jika Suparlan menamai tahap ini sebagai tahap sosialisasi, sehingga ada proses penyajian informasi dari pihak ketiga pada stakeholder sekolah, maka yang terjadi di SD Negeri Tukang 01 dan SD Negeri Tukang 02 justru pemahaman itu lahir dari dalam diri stakeholder sekolah itu sendiri. Stakeholder sekolah sendirilah yang memutuskan bahwa kedua sekolah perlu digabungkan. Temuan di atas juga berbeda dengan temuan penelitian Hills (2013) di New Zealand, bahwa penutupan dan penggabungan sekolah dapat menyebabkan perbedaan budaya masyarakat yang signifikan. Proses regrouping di SD Negeri Tukang 01 dan SD Negeri Tukang 02 tidak menimbulkan konflik budaya di masyarakat sekitar dimana kedua sekolah tersebut berada.

\section{Faktor-Faktor Yang Mempengaruhi Regrouping Sekolah \\ Regrouping sekolah SD Negeri Tukang} 01 dan SD Negeri Tukang 02 dipengaruhi oleh empat faktor, yaitu perundang-undangan tentang regrouping sekolah, kondisi siswa, kondisi kekurangan tenaga pengajar, dan kondisi lingkungan sekolah. Dengan demikian proses regrouping di SD Negeri Tukang 01 dan SD Negeri Tukang 02 sepenuhnya sejalan dengan ketentuan dalam Peraturan Bupati Semarang Nomor 28 tahun 2014 yang mengatur tentang sasaran dari penggabungan sekolah. Menurut Perbup tersebut, sasaran penggabungan sekolah terdiri dari sekolah satu kampus dan sekolah kecil. Kriteria teknis satu kampus yang dimaksud yaitu: 1) dua SD atau lebih terletak di satu lingkungan sekolah, 2) jarak antara sekolah 200 meter atau kurang, 3) jumlah rombel sama dengan ruang kelas yang ada - atau kurang, dan tidak bertentangan dengan Rencana Tata Ruang dan Wilayah (RTRW). Sedangkan syarat untuk sekolah kecil yaitu: 1) Jumlah siswa 80 orang atau kurang, 2) jarak antar sekolah 1.000 meter atau kurang, 3) tidak ada hambatan akses, 4) dalam satu desa terdapat lebih dari satu SD Negeri, 5) tidak berada di daerah perbatasan kabupaten, dan 6) tidak bertentangan dengan RTRW (USAIDPrioritas, 2015: 1). Tampak bahwa regrouping SD Negeri Tukang 01 dan SD Negeri Tukang 02 menjadi SD Tukang memenuhi persyaratan yang ditetapkan Peraturan Bupati baik dari segi sekolah satu kampus (terletak di satu lingkungan sekolah, jarak antar sekolah 200 meter atau kurang, dan jumlah rombel sama dengan ruang kelas yang ada) maupun sekolah kecil (jumlah siswa 80 orang atau kurang, jarak antar sekolah 1.000 meter atau kurang, tidak ada hambatan akses, dalam satu desa terdapat lebih dari satu SD Negeri, dan tidak berada di daerah perbatasan kabupaten).

Temuan di atas sejalan dengan hasil penelitian Dwiningrum \& Widiowati (2014) tentang proses regrouping sekolah yang terdampak erupsi Gunung Merapi di Yogyakarta yang menunjukkan bahwa kebijakan pemerintah daerah merupakan faktor pendukung keberhasilan regrouping sekolah.

\section{Dampak Program Regrouping Sekolah}

Hasil penelitian menunjukkan bahwa terdapat dampak positif maupun negatif dalam proses regrouping di SD Negeri Tukang 01 dan SD Negeri Tukang 02. Dampak positif mencakup 1) teratasinya masalah kekurangan guru; 2) teratasinya masalah kekurangan jumlah siswa, 3) efisiensi pembiayaan melalui dana BOS, dan 4) meningkatnya mutu pendidikan di sekolah. Program regrouping dapat mengatasi masalah kekurangan tenaga pendidik. Pemerintah tidak perlu lagi menempatkan guru dan Kepala Sekolah di SD Negeri Tukang 01. Karena dengan adanya regrouping sekolah, karena otomatis guru olahraga dan kedudukan Kepala Sekolah sudah terisi dari SD Negeri Tukang 02. Sedikitnya jumlah siswa pada kedua sekolah dengan sendirinya teratasi ketika sekolah digabung menjadi satu. Jumlah siswa yang bertambah sangat menguntungkan sekolah karena dapat 
Kelola: Jurnal Manajemen Pendidikan, Vol. 5, No. 2, Juli-Desember 2018

meningkatkan jumlah bantuan dana BOS. Dengan dana yang relatif besar, maka semua kegiatan peningkatan mutu pendidikan sekolahpun dapat dilaksanakan. Peningkatan mutu pendidikan membawa pengaruh terhadap prestasi sekolah yang semakin meningkat pula. Banyak kejuaraan yang diraih oleh SD Negeri Tukang. Namun, regrouping sekolah juga menimbulkan dampak negatif berupa kekecewaan para guru yang dimutasi dan kesulitan bagi para guru honorer dalam memenuhi jam mengajar. Dampak lain yang dirasa sangat merugikan adalah bagi alumni sekolah diregrouping adalah berhubungan dengan legalisasi ijazah sekolah.

Temuan di atas membenarkan kebijakan pemerintah untuk melaksanakan regrouping sekolah baik yang berada dalam satu kampus maupun yang termasuk dalam kategori sekolah kecil sebagaimana diatur dalam Peraturan Bupati Semarang Nomor 28 tahun 2014 (USAID-Prioritas, 2015: 1). Namun temuan ini berbeda dengan hasil penelitian Waluya (2014) tentang pelaksanaan program regrouping Sekolah Dasar 1 Undaan Tengah Kecamatan Undaan Kudus, yang menunjukkan bahwa pelaksanaan program regrouping di SD tersebut berjalan sangat baik sesuai dengan yang diharapkan. Sebab dalam penelitian ini ditemukan bahwa walaupun proses regrouping alami sudah dijalankan oleh stakeholder kedua sekolah namun Surat Keputusan peresmian regrouping baru terbit sesudah proses alami itu berjalan selama 4 (empat) tahun.

\section{Tujuan Regrouping Sekolah (Efektifitas Dan Efisensi dari Regrouping)}

Hasil penelitian menunjukkan bahwa regrouping SD Negeri Tukang 01 dan SD Negeri Tukang 02 menjadi SD Tukang dapat mencapai efisiensi dan efektifitas dalam hal tenaga pendidik dan keuangan sekolah. Namun demikian regrouping itu belum mampu menujukkan efisiensi dan efektifitas dalam pengelolaan sarana prasarana sekolah.
Temuan di atas untuk sebagian sejalan dengan hasil penelitian Purwaningsih (2014) yang menunjukan bahwa program regrouping menujukkan ketercapaian tujuan, yaitu pemenuhan standar pelayanan minimal pendidikan, efisiensi anggaran, efektivitas penyelenggaraan pendidikan, dan adanya peningkatan mutu pendidikan bagi sekolah regrouping, baik dari segi akademis maupun non akademis.

\section{SIMPULAN DAN SARAN Simpulan}

Kesimpulan yang dapat ditarik oleh peneliti dari seluruh proses penelitian ini adalah sebagai berikut:

1. Proses regrouping SDN Tukang 01 dan SD $\mathrm{N}$ Tukang 02 sudah dimulai secara alami atas inisiatif stakeholder sekolah jauh sebelum Surat Keputusan regrouping dari Bupati diterbitkan. Tahapan regrouping meliputi sosialisasi, pembentukan panitia, pelaksanaan regrouping dan turunnya SK regrouping sekolah.

2. Faktor-faktor yang memungkinkan terjadinya program regrouping sekolah adalah: perundang-undangan tentang regrouping, kurangnya jumlah siswa, kurangnya tenaga pendidik, dan kondisi lingkungan sekolah.

3. Regrouping sekolah di SD Negeri Tukang 01 dan SD Negeri Tukang 02 menimbulkan dampak positif maupun negatif. Dampak positif program regrouping adalah a) menjawab kebutuhan tenaga pendidik, b) memenuhi jumlah siswa sesuai standar peningkatan mutu; c) meningkatnya sarana prasarana sekolah khususnya alat-alat peraga dalam proses belajar mengajar; d) meningkatnya prestasi sekolah; dan e) keuangan sekolah menjadi lebih efektif. Dampak negatif regrouping dirasakan oleh guru PNS yang dimutasi ke sekolah yang jaraknya lebih jauh dari tempat tinggal, guru honorer sekolah yang kehilangan jam 
Evaluasi Program Regrouping Sekolah Dasar Negeri | Maria T. Erowati, dkk.

mengajar dan harus mencari sekolah baru, dan alumni yang perlu meluangkan waktu dan mengeluarkan dana lebih banyak untuk melakukan legalisir ijazah di sekolah lama, karena harus ke Dinas Pendidikan Kabupaten Semarang.

4. Dari tujuan regrouping sekolah efektifitas dan efisiensi terjadi dalam pengelolaan tenaga pendidik, mutu pendidikan dan pengelolaan keuangan, namun belum terjadi dalam hal pengelolaan sarana prasarana.

\section{Saran}

Saran yang bisa diberikan berdasarkan simpulan hasil penelitian ini adalah:

1. Bagi Kepala Sekolah. Kepala Sekolah hendaknya memikirkan pengelolaan ruang kelas yang kosong untuk kegiatan yang lebih bermanfaat, misalnya untuk penyelenggaraan pembelajaran maupun ujian SMP Terbuka, untuk ruang laboratorium komputer, atau sekretariat kegiatan KKG Gugus.

2. Bagi Kepala UPTD Pendidikan dan Pengawas SD/TK. Hendaknya senantiasa bekerja sama melakukan monitoring terhadap jalannya regrouping sekolah, dan mencari jalan keluar bagi para alumni supaya bisa melakukan legalisir secara mudah.

\section{DAFTAR PUSTAKA}

Adrian Sutedi. 2007. Hukum Perbankan: Suatu Tinjauan Pencucian Uang, Merger, Likuidasi dan Kepailitan. Jakarta: Sinar Grafika.

Arikunto Suharsimi dan Cepi Safrudin. 2009. Evaluasi Program Pendidikan: Pedoman Teoritis Praktis Bagi Mahasiswa dan Praktisi Pendidikan, cetakan ketiga. Jakarta: Bumi Aksara.

Dwiningrum Siti Irene Astuti \& Rani Widiowati. 2014. School Resiliency And Social Capital of Regrouping Policy After Merapi Eruption in the
Special District of Yogyakarta of Indonesia (A Case Study at SD Umbulharjo 2, Sleman,) https://www.google.com/search?client $=$ firefoxb $\& q=$ school + policy+evaluatio $\mathrm{n}+$ regrouping

Hills, C. 2013. 'Close or be closed: to what extent can school closures and mergers be negotiated?' PhD thesis. Massey University.

Kabupaten Semarang. 2014. Peraturan Bupati Nomor 28 Tahun 2014 tentang Pedoman Teknis Penggabungan Sekolah Dasar Negeri; Semarang: Pemda Kabupaten Semarang.

Kabupaten Semarang. 2014. Surat Keputusan Bupati Semarang Nomor 900/0413/2014. tentang Penetapan Penggabungan Sekolah Dasar Negeri di Kabupaten Semarang; Semarang: Pemda Kabupaten Semarang.

Kemendiknas. 2002. Keputusan Menteri Pendidikan Nasional Nomor 060/U/2002 tentang Pedoman Pendirian Sekolah; Jakarta: Kemendiknas.

Kemendiknas. 2010. Renstra Departemen Pendidikan Nasional 2010-2014. Jakarta: Kemendiknas.

Kemendagri. 1998. Keputusan Menteri Dalam Negeri Nomor 421.2/2501/ Bangda/1998 tentang Pedoman Pelaksanaan Penggabungan Sekolah (Regrouping) SD. Jakarta: Kemendagri.

Provinsi Jawa Tengah. 2012. Peraturan Daerah Provinsi Jawa Tengah Nomor 4 Tahun 2012 tentang Penyelengagaraan Pendidikan: Semarang: Pemda Jawa Tengah.

Provinsi Jawa Tengah. 2013. Peraturan Gubernur Nomor 56 tahun 2013 tentang Petunjuk Pelaksanaan Peraturan Daerah Provinsi Jawa Tengah Nomor 4 Tahun 2012 tentang Penyelenggaraan 
Kelola: Jurnal Manajemen Pendidikan, Vol. 5, No. 2, Juli-Desember 2018

Pendidikan; Semarang: Pemda Jawa Tengah.

Purwaningsih, Ika 2014. Implementasi Kebijakan Regrouping Sekolah Dasar di Kabupaten Purworejo. E-Jurnal Universitas Negeri Yogyakarta; Vol III, No 3: 1 .

Republik Indonesia. 2000. Undang-undang Nomor 25 Tahun 2000 tentang Program Pembangunan Nasional (Propenas) Tahun 2000-2004; Jakarta: Depdagri

Sugiyono. 2010. Memahami Metode Penelitian Kualitatif. Bandung: Alfabeta.

Suparlan. 2006. Merger Sekolah Begitu Perlukah,http://www.suparlan.com/mer ger-sekolah-dasar-begituperlukah59. php.htm pada tanggal 13 Juni 2016 jam 10.05 WIB.

Syahidah, Jihan Amalia 2013. Evaluasi Kebijakan Penggabungan Sekolah
Dasar Negeri Kota Pekalongan. Tesis.PPs-UNY.

USAID.Prioritas. 2015. Regrouping SDN di Kabupaten Semarang, satu langkah dalam Penataan dan Pemerataan Guru. http://prioritaspendidikan.org/id/media/ view/detail/418 pada tanggal 15 Juni 2016, jam 19.10 WIB.

Waluya, Puji. 2014. Pelaksanaan Program Regrouping Sekolah Dasar 1 Undaan Tengah Kecamatan Undaan Kudus. Masters thesis, Universitas Sebelas Maret.

Wibawa, Sarwa. 2009. Dampak penggabungan sekolah dasar terhadap efisiesni, keefektivan, produktivitas, dan pelayanan pendidikan di Kabupaten $b$ Bantul.Tesis. PPs-UNY.

Wirawan. 2011. Evaluasi Teori, Model, Standar, Aplikasi dan Profesi. Jakarta: Raja Grafindo Persada. 